\title{
Using Experiential Education to Develop Human Resources for the Nonprofit Community: A Course Study Analysis
}

\author{
Ann C. Hodges*
}

\begin{abstract}
In this era of shrinking resources and increased pressure to produce "practice-ready" lawyers, law schools are seeking new and cost-effective ways to provide experiential education. This article reports and analyzes the results of a survey of graduates and students from a course in Nonprofit Organizations that incorporated a community-based project designed to develop skills, enhance learning and encourage post-graduation involvement with nonprofits. Although limited to one course, this course study, like a case study, offers valuable information. Consistent with other research on

\footnotetext{
*Ann C. Hodges is Professor of Law, University of Richmond. I am deeply grateful for the extensive help and support of the Community-Based Learning Writing Group and Theresa Dolson, Manager, Community-Based Learning, University of Richmond, as I developed this project. Paul Birch, Computer Services Librarian at the University of Richmond School of Law provided indispensable assistance in constructing and administering the survey. I also would like to thank the participants in the University of Richmond School of Law Summer Workshop Series for their constructive comments on an earlier draft of the article and William Warwick, J.D., University of Richmond, 2012 for valuable research assistance. Finally, I would like to thank Phyllis Katz, my cherished collaborator of twenty years and co-teacher of this class, who shares the responsibility for the existence and success of the class.
} 
experiential education, the survey supports the conclusion that such projects, while less resource intensive and comprehensive than clinics, offer benefits to both the students and to the community. 


\section{Table Of Contents}

INTRODUCTION............................................... 4

I. NonPRofit ORganizATIONS Class AND

SURVEY.................................................... 7

A. The Class and its Evolution................. 9

B. The Survey Methodology.................... 13

II. RESULTS AND ANALYSIS............................ 16

A. Overall Results................................. 16

1. Post-Graduation Non-Profit

Work......................................... 16

2. Educational Outcomes...................... 18

B. Analysis of Overall Results............... 21

C. Internal Comparisons....................... 24

1. Comparison of Results for Law and Business Students........................ 24

2. Graduate Comparison to Current Class.............................................. 28

3. Comparisons Between Classes with Different Projects......................... 30

4. Comparison of Results for Those With and Without Experience Preceding Professional School.......................... 34

III. Lessons For EduCATORS................... 36

CONCLUSION.............................................. 40 


\section{INTRODUCTION}

Recent comprehensive analyses of legal education have urged the incorporation and integration of more practical experiential education into the law school curriculum. ${ }^{1}$ According to critics, law schools teach the theoretical far more thoroughly and effectively than they teach the practical. ${ }^{2}$ Since these analyses, two related phenomena arising from the economic tsunami that began in 2007 have heightened the emphasis on teaching practical legal skills. First, the market for legal services has changed, reducing the ability and inclination of law firms to invest in associates and their training. Second, as a result of the changing market for legal services, the job market for law graduates has tightened. Both have intensified the demand for "practice-ready" lawyers. ${ }^{3}$ And indeed, in this era of declining law school applications, schools which offer extensive experiential education designed to produce "practice-ready" lawyers are bucking the trend, demonstrating the attractiveness of these programs to prospective students. $^{4}$

\footnotetext{
${ }^{1}$ See William M. Sullivan, Et Al., Educating LaWyers: Preparation FOR THE PROFESSION OF LAW (Jossey-Bass 2007) (commonly known as the “Carnegie Report”); AMERICAN BAR ASSOCIATION SECTION OF LEGAL EDUCATION AND ADMISSIONS TO THE BAR, AN EDUCATIONAL CONTINUUM, REPORT OF THE TASK FORCE ON LAW SCHOOLS AND THE PROFESSION: NARROWING THE GAP (1992) (commonly known as the “MacCrate Report”).

2 Sullivan, ET AL., supra note 1, at 7-14, 115-22.

3 The American Bar Association in 2011 adopted a resolution encouraging law schools to develop "practice-ready lawyers." New York State Bar Association, New York State Bar Resolution Calls for "Practice Ready Lawyers",

http://www.nysba.org/AM/Template.cfm?Section=Home\&Template=/CM/HTM LDisplay.cfm\&ContentID=53622, Aug. 11, 2011.

4 See Ethan Bonner, Law Schools' Applications Fall as Costs Rise and Jobs Are Cut, N.Y. TIMES, Jan. 31, 2013 (noting that Northeastern, which has long operated a coop program, has one of the smallest decreases in applications);
} 
At the same time, economic reversals have increased the demand for both community volunteers and public interest lawyers, in addition to enhancing the need for effective nonprofit organizations to provide assistance to the needy. Donations to charity have dropped substantially since before the recession and have not bounced back as quickly as expected. ${ }^{5}$ As funding has decreased and need has increased, nonprofits have turned to volunteers to replace laid off staff, in addition to merging and increasing efficiency. ${ }^{6} \quad$ Like other nonprofits, legal services organizations have been overwhelmed by the increasing demand for legal services for low income individuals, leading to pressure for more pro bono representation from the private bar. ${ }^{7}$

At the confluence of these trends are courses that utilize experiential education both to develop skills and to provide and encourage work benefiting the broader community. These courses involve students in community volunteer work that is integrated into the classroom. The primary model for providing such

William D. Henderson, Washington \& Lee is the Best Legal Education Story of 2013, The Legal Whiteboard, Jan. 29, 2013, http://lawprofessors.typepad.com/legalwhiteboard/2013/01/biggest-legaleducation-story-of-2013.html (noting the significant increase in applications and yield on admissions offers at Washington and Lee which has instituted an experiential education program for the third year of law school).

5 See Holly Hall, Giving by the Rich Dropped \$30-Billion During Recession, CHRONICLE OF Philanthropy, Aug. 29, 2012, http://philanthropy.com/blogs/prospecting/giving-by-the-rich-dropped-30billion-during-recession/34700.

${ }^{6}$ Shelly Banjo \& S. Mitra Kalita, Once-Robust Charity Sector Hit with Mergers, Closures, WALL ST. J., Feb. 2, 2010, http://online.wsj.com/article/SB100014240527487045865045746544042276412 32.html.

\footnotetext{
7 The Legal Services Corporation, Report of the Pro Bono Task FORCE 1-2 (July 2012), available at http://www.lsc.gov/sites/default/files/LSC/pdfs/Pro\%20Bono\%20Task\%20Forc e\%20Report\%20of\%20the\%20Legal\%20Services\%20Corporation.pdf.
} 
education in law has been clinical legal education but it is resource intensive, limiting the availability in many settings. Other models for providing such education are emerging in law schools and will become increasingly important with the combined pressure for keeping costs of legal education lower while at the same time preparing more "practice-ready" lawyers. Community-based learning outside law ${ }^{8}$ offers models that provide similar benefits with fewer resources.

This article analyzes a course in Nonprofit Organizations which used alternative models of experiential education to engage with nonprofits in the community. This course study is like a case study in law. It provides an opportunity to analyze the dynamics of a case, or course, in a particular context. While the approach is necessarily limited because it does not answer the question of how broadly the insights apply, it is a valuable analytical tool in law and can provide the same benefits in analyzing legal education.

The impact of the course was assessed utilizing a survey of students and graduates to determine whether the course met the twin goals of enhancing learning, particularly of practical skills, and encouraging effective post-graduation involvement in the community. Although the sample size for the survey was too small for statistical analysis of the results, the graduates' own assessment of their learning, particularly when viewed from the hindsight of several years of work, provides useful insights regarding the value of experiential education. The survey respondents overwhelmingly supported the conclusion that the experiential education projects incorporated in the class enhanced their learning and developed their skills, in addition to encouraging their involvement in nonprofit organizations after graduation. These results suggest that

8 Community-based learning is also known as service learning. I will use the terms interchangeably in this article to describe course work where students volunteer with community organizations doing work that is integrated into the classroom. JANET EYLER \& DWIGHT E. GILES, JR. WHERE'S THE LEARNING IN SERVICE-LEARNING? 3-5 (Jossey-Bass 1999). 
community engagement projects incorporated into traditional law classes can provide benefits both in and outside the classroom, while occupying fewer resources than the very valuable traditional clinical programs.

Part I describes the class and its goals, which are consistent with the goals of experiential learning in general, and presents the survey methodology. Part II reports and analyzes the survey results to determine whether the course met the goals, putting the results and analysis in the context of the literature and other studies of both legal education and community-based learning outside law schools. Part III concludes with lessons from the survey results for legal educators interested in incorporating experiential learning into their own classes.

\section{NONPROFIT ORGANIZATIONS CLASS AND SURVEY}

To put the Nonprofit Organizations course in context, it is helpful to review briefly the goals and benefits of communitybased learning in general and experiential legal education in particular. The movement in clinical legal education to provide skills based learning while advancing the public interest and the community-based learning movement in undergraduate education emerged at roughly similar times and focus on similar goals. ${ }^{9}$ Enhancing education through engagement in activities using practical skills to benefit the community is common to both forms of education. ${ }^{10}$ Underlying experiential education is a belief that

${ }^{9}$ Id. at 5-22; Elliott S. Milstein, Clinical Legal Education in the United States: In-House Clinics, Externships and Simulations, 51 J. LEG. EdUC. 375, 375 (2001).

10 Not all experiential legal education provides community benefit as some programs assist private clients who might otherwise have access to legal services. For example, Northeastern Law School's coop program, which requires students to complete four fulltime internships of three months each, includes work for private law firms. See Daniel J. Givelber, et al., Learning Through Work: An Empirical Study of Legal Internship, 45 J. LEG. EDUC. 1, 7 
students learn more when they are engaged ${ }^{11}$ and that learning in context is more powerful. ${ }^{12}$ In legal education, the development of experiential learning is one response to the widespread criticisms of the traditional curricular model that emphasizes learning doctrine over skills. ${ }^{13}$ The Nonprofit Organizations class was

(1995). Simulations and problem-based courses do not provide any direct community benefit, but focus on skills training.

11 This conclusion is based on the educational theories of John Dewey. See GERALD F. HESS, ET AL., TECHNIQUES FOR TEACHING LAW 153-4 (Carolina Academic Press 2011) (quoting John Dewey). See also Jennifer Erkulwater, Does it Work? Assessing Community-Based Learning in Political Science, at 23, Annual Meeting of the American Political Science Association, Toronto, Canada, Sept. 3-6, 2009, http://papersssrn.com/sol3/papers.cfm?abstract_id=1448974_ (discussing grounding of community-based learning in Dewey's theories of education).

12 See, e.g., HESs, supra note 11, at 2, 154 (citing various educational theorists who recognized the value of learning through experience); EYLER \& GILES, supra note 8, at 91; Givelber, supra note 10, at 1, 9-10; Deborah Maranville, Infusing Passion and Context into the Traditional Law Curriculum Through Experiential Learning, 51 J. LEG. EdUC. 51, 52 (2001. See also Kristen Holmquist, Challenging Carnegie, 61 J. LEG. EDUC. 353, 368-73 (2012) (discussing the insights of cognitive psychology as applied to legal education).

13 For a summary of the criticisms of legal education over the years, see DAVID I.C. THOMPSON, LAW SCHOOL 2.0: LEGAL EDUCATION FOR A DigITAL AGE 57-72 (LexisNexis 2009). See also Holmquist, supra note 12, at 354-56 (detailing history of criticisms of legal education and responses). For more specific criticisms based on the failure to develop skills and contexts necessary for the practice of law, see Sullivan, ET AL., supra note 1, Summary, at 6, available http://www.carnegiefoundation.org/sites/default/files/publications/elibrary_pdf_ 632.pdf. Results from student surveys reflect the criticisms as well. The results from the 2011 survey of law student engagement revealed that "[f]orty percent of law students felt that their legal education had so far contributed only some or very little to their acquisition of job- or work-related knowledge and skills." NAVIGATING LAW SCHOOL: PATHS IN LEgAL EDUCATION 9 (2011), http://lssse.iub.edu/pdf/2011/2011_LSSSE_Annual_Survey_Results.pdf. The results from the 2010 survey show that fewer than $60 \%$ of the students felt that law school prepared them well for their professional roles, including such tasks as understanding client needs, understanding professional values and dealing 
designed to incorporate the learning theory and the goals of experiential education.

This section will describe the class that was the subject of the survey and the experiential projects that were undertaken by the students in each class, which evolved over time. It will then describe the survey methodology that was used to assess the outcomes. Following review of the class and the survey will be an analysis of the survey results, placed in the context of experiential education research.

\section{A. The Class and its Evolution}

The Nonprofit Organizations class studied here began in 2005, originated by a fulltime faculty member and a practicing attorney who had cofounded a nonprofit organization. ${ }^{14}$ The original course goals were to develop a model for the expansion of the nonprofit to new geographic areas and to encourage the students to get involved in nonprofit work, either as volunteers or paid employees. The latter goal parallels the community-based learning goal of encouraging civic participation ${ }^{15}$ and the clinical legal education goal of teaching the professional value of serving the underserved. ${ }^{16}$ In addition to providing the motivation to work with nonprofits, the course was designed to give the students the tools for successful nonprofit work, as many nonprofit volunteers and board members lack the knowledge and skills to guide and

with ethical dilemmas. STUDENT ENGAGEMENT IN LAW SCHOOL: IN CLASS AND $\begin{array}{lll}\text { BEYOND } & 2, & 8\end{array}$ http://lssse.iub.edu/pdf/2010/2010_LSSSE_Annual_Survey_Results.pdf.

14 That organization is the Legal Information Network for Cancer (LINC), founded in 1996 to assist cancer patients and families with the legal issues that result from the diagnosis and treatment of cancer. See www.cancerlinc.org.

15 EYLER \& GILES, supra note 8, at 162-63.

16 See Margaret Martin Barry, et al., Clinical Education for This Millenium, the Third Wave, 7 CLINICAL L. REV. 1, 6-15 (2000). 
represent their organizations effectively. ${ }^{17}$ Again, these goals coincide with the goals of experiential learning both within and outside of law schools. The community-based learning project evolved to support these goals. Additionally, like all experiential educators, we hoped that the experiential component would broaden and deepen the students' learning, enabling them to better apply and retain what they learned.

The course, which is offered to both law and graduate business students, has been taught four times and each time a significant component of the class was traditional doctrinal education about the law relating to nonprofit organizations. Among the topics regularly covered were: 1 ) what is a nonprofit organization? 2) charitable purpose; 3) implications and requirements of tax exempt status; 4) legal structure of the entity trusts, corporations and LLCs; 5) financial policies and responsibilities; 6) loss of tax exempt status; 7) duties of care and loyalty; 8) charitable solicitation and related legal issues; 9) governance and organizational policies; and 10) liability for organizations and directors. To supplement the doctrinal learning, we incorporated an experiential project.

Because of the initial focus on creating a model for expansion of a particular nonprofit, the first class developed a manual for starting and operating a nonprofit in Virginia. The students were divided into groups and each group researched and drafted a report on one aspect of starting and operating a nonprofit organization. The five groups, each of which included both law and MBA students, were assigned to the following topics: 1)

17 News stories of legal, ethical and governance problems in nonprofits abound. Perhaps the most recent, highly visible failure is that of the board of the Second Mile charity founded by Jerry Sandusky, recently convicted of numerous counts of child molestation. See Mark Viera, et al., Charity Founded by Accused Ex-Coach May Fold, N.Y. TIMES, Nov. 18, 2011, available at http://www.nytimes.com/2011/11/19/sports/ncaafootball/charity-founded-bysandusky-plans-to-fold.html. 
needs assessment, market analysis and mission identification; 2) forming the organization; 3) obtaining and maintaining tax exempt status and fundraising; 4) operations and governance employment and volunteers; and 5) operations and governance board policies and procedures. In the course of developing their reports the students worked with the existing nonprofit that was the model for expansion, including in the reports recommendations for creating a similar organization. The project involved primarily research and drafting, along with some fact investigation and application of the research to a particular nonprofit "client." The final product was a manual for founding and operating nonprofits in Virginia, which was edited by several students over the summer and posted on the law school's web site for use by the public. ${ }^{18}$

This manual led to the community-based learning projects for the second offering of the class when the professors were contacted by a representative of an informal coalition that wanted assistance starting a nonprofit organization. In the spring of 2007, the students assisted that entity and another to formalize their organizations and obtain tax exempt status. The student groups of law and MBA students worked with their clients to gather information about the organization, draft a mission statement, obtain an employer identification number from the IRS, draft articles of incorporation and bylaws, and complete IRS Form 1023, the application for tax exempt status. During the second half of the semester the students switched clients and drafted operational policies and recommendations for the organizations on liability, political activity and lobbying, ethics and conflicts of interest, and financial and accounting practices. Among the skills utilized were interviewing, fact investigation, research, and drafting legal and policy documents.

\footnotetext{
18 See the manual online at http://law.richmond.edu/people/initiatives/nonprofit.html.
} 
Working with clients proved challenging, as they were starting the organizations in their spare time while maintaining fulltime jobs. Despite their professed intent to be available for the students, the students had difficulty obtaining the necessary information from the clients to complete their projects in a timely manner. While these problems provided lessons in themselves, the stress and fear that their grades would be impacted led to student dissatisfaction. This version of the project also demanded the most faculty time, as the work product was being used by the clients to apply for their incorporation and nonprofit status. Thus it was closer to a traditional clinical course than the previous incarnation. As a result of the difficulties and the time demands, the third time through the class, in the fall of 2008, the project changed again.

For the fall 2008 class, the faculty recruited a variety of nonprofit organizations in the community to work with the students. Each group of law and business students interviewed the designated organization's staff and board members and reviewed the official documents of the organization. Their assignment was to assess whether the organization was meeting the legal requirements for nonprofit organizations and to determine whether it was following good governance practices. In addition, the students learned about the organization's mission and assessed compliance with the mission throughout the operations of the entity. Further, the group investigated the unique issues relating to the particular type of nonprofit. Each group then wrote a report, which was shared with the organization, and made a class presentation about the organization and the assessment of its structure, policies and practices, as well as the unique issues that arise for similar organizations. Among the organizations studied were an arts organization, an educational organization, a business/trade association, a health care organization, and an advocacy organization.

This project worked well, so in the spring of 2011, it was repeated. Because the organizations were less diverse, we omitted the requirement that the students teach the class about different 
types of 501(c) organizations while adding a requirement that the students assess the consistency of communication about the mission in marketing and fundraising materials. Organizations studied in this class included a museum, two organizations working with homeless and/or low income populations, an environmental organization, and two organizations working with children and families. The project assignments in the 2008 and 2011 classes utilized skills of interviewing, fact investigation, research, application of legal and business principles to particular facts learned from clients, drafting reports, and making oral presentations.

As is evident from the prior descriptions, the communitybased learning project evolved over time as we explored the most effective way to achieve our teaching goals. The primary goals, however, remained the same - to encourage students use their legal and business skills to support nonprofit organizations and to provide the students with the skills to be outstanding board members, other volunteers, or employees of nonprofits. Additionally we believed that the community-based learning project would enhance student learning by allowing them put the theory into practice. While some students provided positive feedback and some immediate results were evident, ${ }^{19}$ the more formal assessment of the impact of the project described below provides more systematic information about the course. Additionally, it enabled capture of the students' evaluation of the course in light of their subsequent experience in the practice of law or business.

\section{B. The Survey Methodology}

19 For example, several students volunteered for their assigned organization after the project was completed. At least one student decided to do her MBA capstone project with the organization that she worked with in the class. Several applied to serve on boards of other nonprofit organizations. 
In order to assess the course and its impact, a survey was designed and administered to discover whether the students, based on their post-graduation experience, believed that the course had met its goals and achieved the learning outcomes attributed to experiential education. The survey was administered to graduates who took the course in 2005, 2007 and 2008. In addition, a similar survey was administered to the students at the conclusion of the spring 2011 class to compare results.

The questions on the survey were designed to elicit the graduates' evaluation of the effect that the community-based learning project had on their decision about whether to engage in nonprofit work, either volunteer or paid, and the impact that the project had on their learning outcomes. The questions were derived from both the course goals and the literature on experiential education in law and undergraduate school. ${ }^{20}$ The number of questions was limited in order to encourage participation. Because the sample was small, demographic questions were limited to preserve anonymity. The survey takers were asked which year they took the class in order to determine whether different projects had different effects. They were also asked whether they were law, MBA or Masters of Accounting students or some combination thereof. Finally they were asked whether they had returned to graduate or professional school after a break from education to determine whether prior work experience might affect the outcomes. The survey given to the 2005, 2007 and 2008 classes is reproduced as Appendix 1, while

20 The After the J.D. Survey of law graduates, for example, asked about the impact of experiential education on the transition to law practice. Rebecca Sandefur \& Jeffrey Selbin, The Clinic Effect, 16 CLINICAL L. REV. 57, 82-3, 8586 (2009). Eyler and Giles' survey of students involved in service learning asked about the impact of service learning on educational outcomes and also on the students' expectation of participation in community service in the future. EYLER \& GILES, supra note 8, at 83, 162. 
the slightly modified version given to the 2011 class is reproduced as Appendix 2. ${ }^{21}$

To reach the graduates, I obtained contact information from the university alumni office. There were a total of 72 students who took the class during the first three years. Using a combination of letters and e-mails, I acquired a total of 56 good e-mail addresses. $^{22}$ Of those 34 completed the full survey for a response rate of $61 \%{ }^{23}$ Six students from the 2005 class responded, 15 from 2007 and 13 from 2008.

There are inherent limitations in drawing conclusions from this survey. The small number of potential and actual respondents is one. There was no control group as there was no similar course that did not contain a community-based learning component. Any comparisons between courses that the respondents were making used the other courses that they chose to take, which certainly varied by student. Additionally, there are unquestionably limits in asking individuals to assess their own learning. ${ }^{24}$ They may not report accurately, either because they are motivated to provide or not provide particular responses or because they do not accurately perceive what actually occurred. ${ }^{25}$ Since the survey was conducted by their professor, they might be motivated to try to please.

21 The changes related to the fact that the 2011 class could only indicate whether they intended to engage in nonprofit work after taking the class, not whether they had engaged in nonprofit work since taking the class.

22 Good addresses were those that did not lead to a return of an introductory e-mail as undeliverable. I have no way to know whether all of the e-mails actually reached the intended recipient in a timely manner, however.

23 One partial completion was omitted from the statistics.

24 EYLER \& GILES, supra note 8, at 20-1; Givelber, supra note 10, at 20.

25 Id. at 21. It is also possible that their assessments may be based on different criteria from each other and from the criteria that educators might apply. Id. 
Several factors should counteract that tendency if it exists, however. The survey was anonymous and completed after graduation when the professor no longer had any ability to influence their academic career. The distance from graduation may lessen any desire to please the professor and provide more objectivity in evaluation. Moreover, some survey takers were critical of the course, which suggests a lack of constraint. As to the second concern, as noted by other researchers, we do not have alternative measures for the assessment of the impact of particular modes of teaching on student learning so we are left with selfreporting as the best measure available. ${ }^{26}$ And the graduates do have several years of experience evaluating their courses and instructors on a regular basis, at least in college and law or graduate school. ${ }^{27}$

Having described the class and survey, I now move to analysis of the results.

\section{RESULTS AND ANALYSIS}

The survey results confirm that, based on the graduates' assessment, the course met its goals of encouraging postgraduation nonprofit work and providing the skills to do such work. Additionally, the respondents overwhelmingly believed that the experiential component of the class enhanced their learning. Below I report these results and place them in the context of other surveys and literature on experiential learning.

\section{A. Overall Results}

\section{Post-graduation nonprofit work}

A significant $70 \%$ of the survey respondents have done either paid or volunteer nonprofit work since taking the class. Of

\footnotetext{
${ }^{26}$ Id. at $21-22$.

27 Id.
} 
those, the majority volunteered but $13 \%$ performed paid work for nonprofits and 22\% have done both paid and unpaid volunteer work. Further, all those who had not done any nonprofit work since graduation expected to do so in the future. ${ }^{28}$ The results are consistent with the research on service learning ${ }^{29}$ and with the After the JD survey of law graduates. ${ }^{30}$

In Eyler \& Giles study of service learning participants, 75\% indicated that they intended to continue participation in community service in the future. ${ }^{31}$ Of lawyers in the After the JD survey, 44\% reported involvement in pro bono work while $41 \%$ reported involvement in other community work. ${ }^{32}$ The higher percentages

28 For example, one participant stated: "I would not change anything. It was a good learning experience. . . . Although I may not be working in the nonprofit world currently, it remains something that I would like to do once I am financially able." Data regarding volunteering by Americans supports the conclusion that the respondents will volunteer in the future. Individuals in the age groups 35-44 and 45 to 54 are most likely to volunteer, while those in their early twenties are least likely to volunteer. U.S. Bureau of Labor Statistics, Volunteering in the U.S., 2011, and Table 1, available at http://www.bls.gov/news.release/volun.nr0.htm, last visited May 22, 2012. Older individuals are not only more likely to volunteer, but they volunteer more hours than younger people. U.S. Bureau of Labor Statistics, Volunteering in the U.S., 2011, Table 2, available at http://www.bls.gov/news.release/volun.t02.htm, last visited May 22, 2012.

29 The service learning research utilized here comes from Eyler and Giles national research on community-based learning in higher education utilizing surveys, focus groups and individual interviews of over 1500 students at twenty colleges and universities. EYLER \& GILES, supra note 8, at 19-20.

30 After the JD is a longitudinal study of the career outcomes of 5000 new lawyers who became eligible to practice law in 2000. See Sandefur \& Selbin, supra note 20 , at $57,82$.

31 EYLER \& GILES, supra note 8, at 162. Because of the timing of the survey, it did not measure what students actually did in the community but only their intent.

32 Sandefur \& Selbin, supra note 20, at 94-96. Other community work included community and charitable organizations, political activity and bar 
of graduates intending to engage in community work in the current study may be explained by two factors. First, the numbers in this survey are much smaller and second, the students here all chose to take a course in nonprofit organizations, suggesting a prior inclination toward such work.

Interestingly, however, the After the JD study revealed no relationship between lawyers' involvement in pro bono or community work and participation in clinical legal education in law school, ${ }^{33}$ while in our survey almost half of the respondents indicated that the community-based learning component of the class positively influenced their decision to engage in nonprofit work. The After the JD study did find an association between clinical legal education and participation in civic activities and public service employment after law school for those students who also reported civic motivations for attending law school, however. ${ }^{34}$ This finding supports the hypothesis that the nonprofit course graduates' participation in nonprofit work was influenced not only by the class, but also by the same motivation that caused them to choose the class.

\section{Educational Outcomes}

The other portion of the survey focused on educational outcomes. A substantial $74 \%$ of those answering the survey agreed $^{35}$ that the assigned project enhanced their skills and knowledge in ways that would enable them to work effectively for nonprofits, and 68\% agreed that they obtained skills and knowledge to be better community citizens in general. Thus the

\footnotetext{
organizations. Id. at 96.

33 Id. at 94-97.

34 Id. at 92-3, 96-7, 98-100.

35 For each of the totals on both the graduate and current student surveys, we counted those who agreed and strongly agreed.
} 
students highly valued the project in improving their skills. This result also accords with other research. Eyler and Giles found that community-based learning classes developed in the students qualities identified as important for effective citizenship - values, knowledge, skills, efficacy and commitment. ${ }^{36}$ Similarly, respondents in the After the JD survey rated experiential education highly in making the transition from law school to law practice. ${ }^{37}$ Summer legal employment was valued most highly, but also helpful were clinical education, internships, school year legal employment and legal writing training. ${ }^{38}$

Similarly, in the National Association of Law Placement study of experiential education, survey respondents ranked clinical programs and externships as useful in the practice of law. ${ }^{39}$ In a study of legal internships, students regarded the educational experience highly and reported improvement in legal skills. ${ }^{40}$ Other studies of practicing lawyers and law students similarly emphasize the value of learning by doing, with advice and feedback as well as observation of skilled practitioners. ${ }^{41}$ These

36 EYLER \& GILES, supra note 8, at 156-64.

37 Sandefur \& Selbin, supra note 20, at 82-3, 85-6.

38 Id. at $85-6,88$. At least $50 \%$ of the graduates with these experiences found them helpful to extremely helpful. Other experiences like traditional courses, both upper-level and first year, ethics training and pro bono work ranked lower. Id. at 85-6.

39 NATIONAL AsSOCiation OF LAW Placement (NALP), 2010 SURVEY OF LAW SCHOOL EXPERIENTIAL OPPORTUNITIES AND BENEFITS 26-27 (2011), available at http://www.nalp.org/uploads/2010ExperientialLearningStudy.pdf

40 Givelber, supra note 10, at 24-5. In the internship study, unpaid jobs rated higher than paid jobs in terms of learning experience. Id. at 29. Judicial and legal aid/public defender internships were deemed most valuable. Id. The authors posit two reasons for this result. The supervision in those offices was rated higher by the students and more students reported that the work assigned in these offices was commensurate with their skill level. Id. at 30-31.

41 Id. at 16-19. 
results fit with the theory of contextual learning. The students are able to learn in the situation, developing patterns from experience that they are then able to apply to future problem-solving. ${ }^{42}$

In addition to the focus on skills development, the survey asked questions designed to assess the impact of the project on learning in general. The results here support prior research on experiential learning even more strongly. An overwhelming 91\% of respondents felt that they learned more in the class as a result of the project. An even larger $94 \%$ agreed or strongly agreed that the project gave context to the classroom component of the course. And $82 \%$ concluded that the project deepened their understanding of the materials studied in the classroom component of the course, while $74 \%$ believed that the community-based project improved their retention of the material presented in assigned readings and classroom lectures and discussions. Finally, in accord with an important goal of experiential learning, $79 \%$ concluded that the project improved their ability to apply what they learned in the class.

These results confirm what other researchers have found. For example, Eyler and Giles similarly discovered that students firmly believed that they learned more from service learning than from traditional classes alone, and that they learned better. ${ }^{43}$ The respondents in their survey reported that they developed a deeper understanding of complex issues and a better sense of how to apply what they learned. ${ }^{44}$ Based on the surveys and interviews as well as learning theory, Eyler and Giles concluded that the "combination of high interest, emotional ties, and rich experiential contexts may be what led our students in well-integrated servicelearning classes to their more complex understanding of the issues

\footnotetext{
42 Id. at 9-11, 43.

43 EYLER \& GILES, supra note 8, at 83.

${ }^{44}$ Id.
} 
as well as their greater practical knowledge. People and situations engaged them so that they wanted to know more, and the combination of real community settings and structured reflection helped them construct rich and complex pictures of issues and processes." 45

\section{B. Analysis of Overall Results}

In sum, results of the surveys here are in accord with other research on experiential learning. The project, which gave the students hands on experience in nonprofit work, was viewed by a majority of the respondents and in many cases, the overwhelming majority of the respondents, as enhancing their learning. Their evaluations indicate that the project resulted in more learning, contextual learning, deepened understanding, improved retention, and greater ability to apply what they learned. These are precisely the goals of experiential education in general, and particularly in law schools. Student comments in the open-ended question about the project support the conclusions reflected in the statistical data. Among them:

"I found the hands-on work to be invaluable."

"Hearing the real challenges and the passion that the organizers had helped put the theoretical material in context."

"I thought that this class, unlike any other that I took during law school, was directly related to real-world experience that could immediately be applied to other clients. Plus, this class, again unlike many others, was actually FUN and interesting because we were directly helping an NPO and could see the benefit of our hard work immediately and tangibly.”

"It was really helpful to get out of the classroom and get involved with real organizations.”

45 Id. at 84. 
"It was valuable to be able to speak with the director of the non-profit organization and hear about her experience with nonprofit organizations. It revealed a very realistic and practical perspective.”

“. . . [T]he project was fun and a helpful learning experience.”

Providing skills training is another important goal, particularly of experiential legal education. While a substantial $74 \%$ of the participants valued the skills training, that percentage is somewhat lower than on the other educational outcome measures. ${ }^{46}$ One explanation may be that the project did not offer the sort of ongoing skills training provided in a semester long clinical experience, whether in house or external. The students learned the substantive material that formed the basis of the project (e.g. what should be included in nonprofit bylaws and why), were provided with detailed written guidance on the project, and received periodic checks by the professors, who answered questions and insured that the project was proceeding as planned. The project did not include ongoing feedback from the professors, simulations, supervised client or court interactions with immediate feedback, or assignments of increasing complexity that built on one another, however.

The latter are characteristic of clinical legal education. While extremely valuable, they require extensive faculty resources dedicated to a smaller number of students. The projects here required more faculty time than teaching a traditional course, but far less than a clinical course. The results demonstrate that the benefits of experiential education can be obtained in other types of courses. The maximum enrollment in the class was 24, significantly more than in the typical clinical course. One reason

46 Respondents' comments reveal the value: “I feel that I could start my own non-profit and that it could be a small one. . . . It was one of my favorite classes in law school.” 
for the limit is to allow student groups to make class presentations on their projects. The class presentations allow the students to learn from one another and to learn about different types of nonprofit organizations and the variations in approach required for different organizations. Dispensing with this aspect of the class could increase the number of projects and thus the number of students who could be accommodated, so long as enough organizations were available to work with the students.

Although the value of skills training was rated lower than other educational outcome measures, it was significantly higher than that found in the After the JD study. ${ }^{47}$ That result may reflect no more than the small numbers in the current study. Nevertheless the comparative results do suggest that valuable skills training can occur using experiential projects as adjuncts to traditional classes.

Critics of legal education have suggested that experiential education will increase students' passion for law school. ${ }^{48}$ The argument is that many students enter law school with a desire to make a difference for people or to engage in public service. ${ }^{49}$ Their actual experience, however, is studying abstract cases devoid of context. $^{50}$ And in traditional courses, issues of justice are not only absent, but discussion of them is often actively discouraged. ${ }^{51}$ Thus, critics posit that experiential education of various forms should tap into these students' motivation. The results of the survey support this hypothesis, with $68 \%$ of respondents reporting increased passion for their educational program as a result of the project. Among the respondents' comments reflecting on this point were the following: "I think the practical experience really added

\footnotetext{
47 See supra note 38.

48 Maranville, supra note 12, at 51, 53-4.

49 Maranville, supra note 12, at 53.

$50 \mathrm{Id}$.

51 Id.
} 
to my overall interest in the subject matter and increased my learning of same." "This class was one I looked forward to after a long day of not-so-interesting law classes." Although these results were not quite as strong as on the other educational outcomes measures, the graduates remained strongly committed to public service, as evidenced by their nonprofit work after graduation.

Finally, the results strongly support the conclusion that public interest work in law classes encourages commitment to such work after law school. While the students here almost certainly had an interest in nonprofit work before taking the class, almost half agreed that the project motivated them to engage in nonprofit work, volunteer or paid, after graduation.

Having looked at the overall results of the survey, I now move to the internal comparisons enabled by the data to see if they reveal additional insight regarding the contribution of the class projects to motivation to engage in nonprofit work and educational outcomes. The survey allows comparison of data for law and business students, for graduates and current students, for different course projects, and for students with and without prior work experience. Those results are reported and analyzed below.

\section{Internal Comparisons}

1. Comparison of Results for Law and Business Students

Because the class was composed of both law and business students, albeit smaller numbers of the latter, the survey enabled comparison of the two groups on the measures of both engagement in nonprofit organizations after graduation and enhancement of learning outcomes.

Tables 1 and 2 compare the results for law and business students on these measures. 
Table 1 Nonprofit Engagement

\begin{tabular}{|l|l|l|}
\hline Question & Law N=27 & Business $^{\text {52 N=7 }}$ \\
\hline $\begin{array}{l}\text { Nonprofit work since } \\
\text { class }\end{array}$ & $70.37 \%$ & $71.43 \%$ \\
\hline Volunteer & $40.74 \%$ & $57.14 \%$ \\
\hline Paid & $7.41 \%$ & $14.29 \%$ \\
\hline Both & $22.22 \%$ & 0 \\
\hline $\begin{array}{l}\text { Project influenced } \\
\text { decision to engage or } \\
\text { not engage in } \\
\text { nonprofit work }\end{array}$ & $48.15 \%$ & $42.86 \%$ \\
\hline $\begin{array}{l}\text { Project made } \\
\text { nonprofit work more } \\
\text { likely }\end{array}$ & $48.15 \%$ & $42.86 \%$ \\
\hline $\begin{array}{l}\text { Project made } \\
\text { nonprofit work less } \\
\text { likely }\end{array}$ & 0 & 0 \\
\hline
\end{tabular}

52 Both MBA and Masters of Accounting students are included in the business student group. 
Table 2 Educational Outcomes

\begin{tabular}{|l|l|l|}
\hline Question & Law N=27 & $\begin{array}{l}\text { Business Class } \\
\mathrm{N}=7\end{array}$ \\
\hline $\begin{array}{l}\text { Project gave } \\
\text { experience and skills } \\
\text { for nonprofit work }\end{array}$ & $74.07 \%$ & $71.43 \%$ \\
\hline $\begin{array}{l}\text { Project gave skills and } \\
\text { experience for } \\
\text { citizenship }\end{array}$ & $70.37 \%$ & $57.15 \%$ \\
\hline $\begin{array}{l}\text { Learned more as a } \\
\text { result of the project }\end{array}$ & $96.29 \%$ & $71.43 \%$ \\
\hline $\begin{array}{l}\text { Project put class } \\
\text { material in context }\end{array}$ & $96.29 \%$ & $85.71 \%$ \\
\hline $\begin{array}{l}\text { Project gave deeper } \\
\text { understanding of } \\
\text { material }\end{array}$ & $85.19 \%$ & $57.43 \%$ \\
\hline $\begin{array}{l}\text { Project improved } \\
\text { retention of the } \\
\text { material }\end{array}$ & $77.78 \%$ & $57.15 \%$ \\
\hline $\begin{array}{l}\text { Project improved } \\
\text { ability to apply what I } \\
\text { learned }\end{array}$ & $85.19 \%$ & \\
\hline $\begin{array}{l}\text { Project increased } \\
\text { passion for } \\
\text { law/business school }\end{array}$ & $74.07 \%$ & \\
\hline
\end{tabular}


While the business school students are equally engaged in post-graduation nonprofit work, their evaluation of the educational benefit of the project is positive, but consistently lower than that of the law students. The explanation may be no more than the small number of business students in the cohort, such that the ranking of one student makes a significant difference in the percentages.

It is also possible that the business school students saw less value in the project. The professors of the class are lawyers and have found it challenging to teach the course to both groups. The business school students have been consistently more critical of the course on regular student evaluations. Also, it is more common for business school classes to use alternative teaching methodologies ${ }^{53}$ so perhaps these students were using a different comparison standard in evaluating the class. One other possibility is that on the projects, the business students focused on the business aspects and the law students on the legal aspects. Thus the project may have done less to enhance their learning about the legal aspects of the class, which they knew less about coming into the class than the law students and undoubtedly found more challenging as a result. On the particular class goal of providing the skills for nonprofit work, however, the ratings of the two groups were extremely close. One reason for opening the class to business students was the great need of nonprofits for business and accounting expertise so the high rating on this measure, suggests that the course met its goal of developing governance expertise among future board members for nonprofits.

53 Sullivan, ET AL., supra note 1, Summary, at 6, available at http://www.carnegiefoundation.org/sites/default/files/publications/elibrary_pdf_ 632.pdf. 


\section{Graduate Comparison to Current Class}

As a check on the results of the survey of graduates, I surveyed the students in the nonprofit organizations class at the conclusion of the 2011 spring semester. The response rate was higher, as the group was asked to complete the survey during class time, ${ }^{54}$ and the results were quite similar. All of the students expected to do future work with nonprofit organizations, either paid or unpaid. Slightly over half indicated that the project positively influenced their decision to engage in nonprofit work, while the others indicated that the project had no influence on the decision. Only half, however, stated that the project increased their passion for law or business school, less than the graduate percentage of 68 .

Table 3 compares the responses to educational outcome questions for the graduates and the 2011 class.

Table 3 Educational Outcomes

\begin{tabular}{|l|l|l|}
\hline Question & Graduates N=34 & 2011 Class N=16 \\
\hline $\begin{array}{l}\text { Project gave } \\
\text { experience and skills } \\
\text { for nonprofit work }\end{array}$ & $73.53 \%$ & $97.5 \%$ \\
\hline $\begin{array}{l}\text { Project gave skills and } \\
\text { experience for } \\
\text { citizenship }\end{array}$ & $67.65 \%$ & $81.25 \%$ \\
\hline $\begin{array}{l}\text { Learned more as a } \\
\text { result of the project }\end{array}$ & $91.18 \%$ & $93.75 \%$ \\
\hline
\end{tabular}

54 Sixteen of the seventeen students completed the survey. 


\begin{tabular}{|l|l|l|}
\hline $\begin{array}{l}\text { Project put class } \\
\text { material in context }\end{array}$ & $94.12 \%$ & $93.75 \%$ \\
\hline $\begin{array}{l}\text { Project gave deeper } \\
\text { understanding of } \\
\text { material }\end{array}$ & $82.35 \%$ & $93.75 \%$ \\
\hline $\begin{array}{l}\text { Project improved } \\
\text { retention of the } \\
\text { material }\end{array}$ & $73.53 \%$ & $100 \%$ \\
\hline $\begin{array}{l}\text { Project improved } \\
\text { ability to apply what I } \\
\text { learned }\end{array}$ & $79.42 \%$ & $81.25 \%$ \\
\hline $\begin{array}{l}\text { Project increased } \\
\text { passion for } \\
\text { law/business school }\end{array}$ & $67.64 \%$ & $50 \%$ \\
\hline
\end{tabular}

Although the numbers are small, limiting the significance of the conclusions, the results from the most recent class are quite similar to those of the graduates. Among student comments were the following:

"The thing that stands out the most is the realization that what I have been learning in law school [is]actually practical in the real world. Rarely have I as a law student really seen the connection between the class materials and its real life application."

"It helped me to understand the work that goes into the non-profit and the areas in which [sic] the common person may not understand."

"I learned much about the problems and challenges that are facing nonprofit organizations today ...." 
The biggest differences between the graduate and student responses are in the students' higher evaluation of the skills and abilities learned and their assessment that the project had a greater effect on retention of the material. These differences may simply reflect the hindsight view of the graduates. The current students may have had an enhanced view of their skills and abilities while remaining in the comfort of law school under the close supervision of faculty. Once out in practice, without the safety net that law school provides and faced with the severe consequences of getting it wrong, the graduates' assessment of their skills and abilities may be less optimistic. Another possible explanation is that the 2007 project may have provided fewer transferable skills, since it was limited to starting a nonprofit. Indeed of the graduates from that year, only $66.67 \%$ indicated that the project gave them the skills and experience to do nonprofit work. While that may have reduced the percentage of the graduates to some extent, it is not likely the full explanation of the difference. Finally, the most recent results may reflect our improvement as teachers in more effectively integrating the community-based project into the course and relating it more directly to the materials we were teaching in the classroom.

\section{Comparisons Between Classes with Different Projects}

The questionnaire responses also allow comparison of the responses based on the type of project. The 2005 project was creation of a manual for starting a nonprofit, while the 2007 students actually assisted clients in starting a nonprofit and the 2008 and 2011 students assessed the compliance of existing nonprofits with legal requirements and good governance practices. Of course, the numbers in each cell are even smaller here but the results are relatively similar. Table 4 compares the responses on engagement in nonprofit work and Table 5 compares the responses on Educational Outcomes. 
Table 4 Engagement in Nonprofit Work

\begin{tabular}{|l|l|l|l|}
\hline Question & $2005 \mathrm{~N}=6$ & $2007 \mathrm{~N}=15$ & $2008 \mathrm{~N}=13$ \\
\hline $\begin{array}{l}\text { Nonprofit work } \\
\text { since class }\end{array}$ & $83.33 \%$ & $60 \%$ & $76.92 \%$ \\
\hline Volunteer & $50 \%$ & $33.3 \%$ & $53.85 \%$ \\
\hline Paid & 0 & $13.3 \%$ & $7.69 \%$ \\
\hline Both & $33.33 \%$ & $13.3 \%$ & $15.38 \%$ \\
\hline $\begin{array}{l}\text { Project } \\
\text { influenced } \\
\text { decision to } \\
\text { engage or not } \\
\text { engage in } \\
\text { nonprofit work }\end{array}$ & $66.67 \%$ & $33.33 \%$ & $53.85 \%$ \\
\hline $\begin{array}{l}\text { Project made } \\
\text { nonprofit work } \\
\text { more likely }\end{array}$ & $66.67 \%$ & $33.33 \%$ & $53.85 \%$ \\
\hline $\begin{array}{l}\text { Project made } \\
\text { nonprofit work } \\
\text { less likely }\end{array}$ & 0 & 0 & 0 \\
\hline
\end{tabular}


Again the differences are probably not large enough to be significant. The graduates from 2007 have been less involved, and were less influenced to be involved, in nonprofit work. In the view of the professors, the 2007 project was the least successful because of difficulties in working with clients founding nonprofits in their spare time. As noted earlier, the limited availability of the clients created problems for the students in getting the information that they needed in a timely manner. ${ }^{55}$ While there were important lessons learned as a result of the complications, ${ }^{56}$ the students' frustrations may have impacted their desire to participate in nonprofit work. Nevertheless, even the 2007 graduates all indicate that they anticipate engaging in nonprofit work at some point.

Table 5 Educational Outcomes

\begin{tabular}{|l|l|l|l|l|}
\hline Question & $2005 \mathrm{~N}=6$ & $\begin{array}{l}2007 \\
\mathrm{~N}=15\end{array}$ & $\begin{array}{l}2008 \\
\mathrm{~N}=13\end{array}$ & $\begin{array}{l}2011 \\
\mathrm{~N}=16\end{array}$ \\
\hline $\begin{array}{l}\text { Project gave } \\
\text { experience and } \\
\text { skills for } \\
\text { nonprofit work }\end{array}$ & $83.33 \%$ & $66.67 \%$ & $76.92 \%$ & $97.5 \%$ \\
\hline $\begin{array}{l}\text { Project gave } \\
\text { skills and } \\
\text { experience for } \\
\text { citizenship }\end{array}$ & $83.33 \%$ & $66.67 \%$ & $61.54 \%$ & $81.25 \%$ \\
\hline
\end{tabular}

55 One respondent said: "I remember thinking that the nonprofits' representatives were not as engaged in the process as they should have been. . . . And, they weren’t terribly responsive when the class needed information.”

56 The students learned valuable lessons about the common challenges of working with clients. 


\begin{tabular}{|l|l|l|l|l|}
\hline $\begin{array}{l}\text { Learned more } \\
\text { as a result of } \\
\text { the project }\end{array}$ & $83.33 \%$ & $93.33 \%$ & $92.31 \%$ & $93.75 \%$ \\
\hline $\begin{array}{l}\text { Project put } \\
\text { class material } \\
\text { in context }\end{array}$ & $83.33 \%$ & $100 \%$ & $92.31 \%$ & $93.75 \%$ \\
\hline $\begin{array}{l}\text { Project gave } \\
\text { deeper } \\
\text { understanding } \\
\text { of material }\end{array}$ & $83.33 \%$ & $80 \%$ & $84.62 \%$ & $93.75 \%$ \\
\hline $\begin{array}{l}\text { Project } \\
\text { improved } \\
\text { retention of the } \\
\text { material }\end{array}$ & $66.67 \%$ & $80 \%$ & $69.23 \%$ & $100 \%$ \\
\hline $\begin{array}{l}\text { Project } \\
\text { improved } \\
\text { ability to apply } \\
\text { what I learned }\end{array}$ & $83.33 \%$ & $73.33 \%$ & $84.62 \%$ & $81.25 \%$ \\
\hline $\begin{array}{l}\text { Project } \\
\text { increased } \\
\text { passion for } \\
\text { law/business } \\
\text { school }\end{array}$ & $66.66 \%$ & $60 \%$ & $76.92 \%$ & $50 \%$ \\
\hline
\end{tabular}

Given the small numbers, the results are again relatively consistent across class projects. Substantial numbers in each group recognized the value of the project in improving their learning outcomes. As mentioned previously, the 2007 project gave students fewer skills to work with ongoing nonprofits as they concentrated on starting an organization, which is likely the cause of the relatively lower scores on the questions about skill 
development. Several student comments on the survey support this conclusion. ${ }^{57}$

4. Comparison of Results for Those With and Without Work Experience Preceding Professional School

The results of the students who attended their professional program immediately after college and those who spent at least a year out of school can also be compared. Tables 6 and 7 show those comparisons.

Table 6 Nonprofit Engagement

\begin{tabular}{|l|l|l|}
\hline Question & $\begin{array}{l}\text { Out of School } \\
\mathbf{N}=\mathbf{2 5}\end{array}$ & $\begin{array}{l}\text { Straight Through } \\
\text { School N=9 }\end{array}$ \\
\hline $\begin{array}{l}\text { Nonprofit work since } \\
\text { class }\end{array}$ & $76 \%$ & $55.6 \%$ \\
\hline Volunteer & $52 \% \%$ & $22.22 \%$ \\
\hline Paid & $8 \%$ & $11.11 \%$ \\
\hline Both & $16 \%$ & $22.22 \%$ \\
\hline $\begin{array}{l}\text { Project influenced } \\
\text { decision to engage or }\end{array}$ & $52 \%$ & $33.33 \%$ \\
\hline
\end{tabular}

57 For example, one comment stated: “The only thing I would suggest changing would be to not limit the project to simply people trying to set up or start a nonprofit, but rather open the project to active nonprofits who face other challenges or questions . . ..” Another said: "My class worked on helping organizations obtain legal status. While this was helpful and very interesting, it would have been more useful to learn more about the inner workings of nonprofits (grant-writing, lobbying, policy-making). A lot of people in the class took it because they wanted to work for a non-profit as counsel, and so just learning how to obtain status wasn't helpful.” 


\begin{tabular}{|l|l|l|}
\hline $\begin{array}{l}\text { not engage in } \\
\text { nonprofit work }\end{array}$ & \\
\hline $\begin{array}{l}\text { Project made } \\
\text { nonprofit work more } \\
\text { likely }\end{array}$ & $52 \%$ & $33.33 \%$ \\
\hline $\begin{array}{l}\text { Project made } \\
\text { nonprofit work less } \\
\text { likely }\end{array}$ & 0 & 0 \\
\hline
\end{tabular}

Table 7 Educational Outcomes

\begin{tabular}{|l|l|l|}
\hline Question & $\begin{array}{l}\text { Out of School } \\
\mathrm{N}=25\end{array}$ & $\begin{array}{l}\text { Straight Through } \\
\text { School N=9 }\end{array}$ \\
\hline $\begin{array}{l}\text { Project gave } \\
\text { experience and skills } \\
\text { for nonprofit work }\end{array}$ & $76 \%$ & $66.66 \%$ \\
\hline $\begin{array}{l}\text { Project gave skills and } \\
\text { experience for } \\
\text { citizenship }\end{array}$ & $72 \%$ & $55.55 \%$ \\
\hline $\begin{array}{l}\text { Learned more as a } \\
\text { result of the project }\end{array}$ & $88 \%$ & $100 \%$ \\
\hline $\begin{array}{l}\text { Project put class } \\
\text { material in context }\end{array}$ & $92 \%$ & $88.89 \%$ \\
\hline $\begin{array}{l}\text { Project gave deeper } \\
\text { understanding of } \\
\text { material }\end{array}$ & $80 \%$ & $66.66 \%$ \\
\hline $\begin{array}{l}\text { Project improved } \\
\text { retention of the }\end{array}$ & $76 \%$ & $100 \%$ \\
\hline
\end{tabular}




\begin{tabular}{|l|l|l|}
\hline material & & \\
\hline $\begin{array}{l}\text { Project improved } \\
\text { ability to apply what I } \\
\text { learned }\end{array}$ & $80 \%$ & $77.77 \%$ \\
\hline $\begin{array}{l}\text { Project increased } \\
\text { passion for } \\
\text { law/business school }\end{array}$ & $72 \%$ & $55.55 \%$ \\
\hline
\end{tabular}

Those students who went straight through school are somewhat less likely to have engaged in nonprofit work since taking the class, although all intend to do so in the future. This result may be explained, at least in part, by the fact that older individuals are more likely to volunteer. ${ }^{58}$ Fewer of the students who went straight through school believed that the course gave them the skills and experience to do nonprofit work or to be better citizens and fewer stated that the project increased their passion for school, but in general they saw the project as improving their learning in the same ways as the students who spent time out of school. It is possible that the students with more experience between college and law or business school felt more confident and comfortable with the project and better able to utilize the experience for the future.

\section{LESSONS FOR EDUCATORS}

The survey results confirm the results of other research on the impact of experiential education. In addition, they offer useful information for others contemplating the use of community-based learning projects in similar courses. I summarize below the conclusions that can be drawn from the survey. In addition to the course goals expressly assessed by the survey, I also note some

58 See supra note 28. 
additional benefits of inclusion of similar projects in law school classes.

Since the survey results indicate that course met the goal of encouraging students to engage in nonprofit work, faculty teaching nonprofit organizations courses may want to consider incorporating an experiential component. Of course, the students who chose to take this course may have been likely to volunteer or work with nonprofits in any event, but nearly half indicated that their participation in the community-based project increased the likelihood of post-graduation community involvement. Interestingly, the engagement in nonprofit work post-graduation was much higher than that reflected in the After the JD survey of law students and greater than that anticipated in Eyler and Giles' survey of community-based learning students at the undergraduate level. ${ }^{59}$ The contrast with the After the JD survey is particularly interesting as participation in clinical education was not associated with pro bono representation at all or with civic participation and public service work except as mediated by prior civic motivation for attending law school. ${ }^{60}$ The explanation may be that students took Nonprofit Organizations because of a particular interest in nonprofit work, while students may choose a clinical course for the skills training alone.

The skills enhancement provided by the experiential project provides an additional reason for faculty to consider including such a component in their classes. With the very public failures of oversight of nonprofits, development of expertise in nonprofit representation and governance provides value to society. Additionally the survey results also supported other claims of proponents of experiential education - that it enhances learning and improves practical skills, enabling students to better apply what they have learned in real world settings. Thus, law faculty

59 See supra notes 31-32 and accompanying text.

60 See supra notes 33-34 and accompanying text. 
seeking to meet the current criticisms of legal education and the demand for more practice-ready lawyers can utilize similar models to incorporate contextual learning into the classroom. While caution is required in interpreting data from the small numbers, the results are fully consistent with the results of other surveys of experiential education.

A course in the law and business of nonprofit organizations provides an opportunity for students to learn skills, other than litigation skills, that can be used to further social justice goals. Lawyers, accountants and business experts can be essential components in building and operating nonprofit organizations that serve the public interest. Nonprofits need knowledgeable and effective board members to establish policy, guide decisions, insure compliance with laws, policies, and ethical norms, and provide expert assistance to staff and volunteers. Without such a board, the nonprofit is likely to run off the rails despite the good intentions that motivate founders, volunteers and staff. ${ }^{61}$ The results of the survey of graduates suggest that incorporating a community-based learning component in the class will not only assist existing nonprofits, but also encourage and equip students to become engaged with nonprofits after graduation.

The course also provides a model that can be used to incorporate an experiential component in a traditional law school class with fewer resource demands than a full-scale clinical course. Faculty considering revising courses to include a community-based project should draw from our experience lessons in structuring the

61 See supra note 17. See also Reid K. Weisbord, Charitable Insolvency and Corporate Governance in Bankruptcy Reorganization, 10 BERKELEY BUS. L.J. No. 2 (forthcoming 2013) available at SSRN http://papers.ssrn.com/sol3/papers.cfm?abstract_id=2188940 (noting the substantial problems of corporate governance of nonprofit organizations, the limited governmental oversight of these organizations, and the importance of their impact given the public subsidy of their operations and the consequent requirement that they operate for public benefit). 
course. Doing legal work for real clients that will be used by the clients for more than self-assessment purposes takes substantially more faculty time than other projects. And working with nonprofit start-ups run by volunteers creates difficulties in student access to clients that may be difficult to overcome despite the clients' good intentions. Some projects may be very valuable but can only be done once, such as the manual for starting and operating a nonprofit. Projects must be carefully designed to provide benefit to the students and minimal disruption to the nonprofit. Commitment of the nonprofit's leadership was, in each case, essential to the success of the project.

The benefits of similar community-based learning projects are not limited to courses in Nonprofit Organizations. The model used here teaches transactional, drafting, interviewing, evaluation and advising skills, rather than litigation skills. ${ }^{62}$ Thus it might be adapted for use in other courses where such skills would be valuable, such as corporate, contracts, tax, employment, or intellectual property classes. To continue the focus on community benefit, faculty might identify nonprofits interested in assistance with issues studied in these classes.

Faculty considering implementing similar projects should also be aware of several other benefits that were not specifically tested on the survey but were incorporated in the project intentionally and recognized by some respondents in their freestyle comments. The project gave the students an opportunity to work in teams, a skill valued in today's workforce, and provided law and business students the opportunity to work together and learn from each other's expertise. Additionally, the project gave the students an opportunity to develop working relationships with CEOs, high level managers of organizations, and board members who are often

62 Most experiential learning opportunities in law school focus on litigation rather than transactional skills. NALP, supra note 39, at 27. 
prominent community citizens. ${ }^{63}$ Students were quite impressed to be trusted by those individuals to receive and respond to confidential information and to provide valued recommendations about the organization. ${ }^{64}$ Finally and perhaps most rewarding, the students learned about a variety of important community nonprofits and saw the benefits provided by the organizations and the passions of their staff, board and supporters. ${ }^{65}$ These lessons will redound to the benefit of both the professionals and the communities in the long term.

\section{CONCLUSION}

Experiential education, particularly using work with community organizations, has the potential to provide benefits to both the students and the organizations, in the short term ${ }^{66}$ and in the long term. The nonprofit organizations course profiled here offers a model of such a class which requires fewer institutional

63 The size of the chosen organizations was varied intentionally to provide a wide range of experiences, from single employee organizations to those with several hundred employees.

64 As one student stated: "I enjoyed having an inside look at an organization and having top management trust us with their views on their own organization.”

65 One participant valued "[l]earning about an organization that I never would have had I not had this project. And then actually getting to meet the people that run the organization to really get a true life opportunity to see what the organization is really about and to discover the passion behind the organization.” Another stated: What stood out to me was meeting the CEO of the company I worked with. I felt like I got a firsthand look at the company and I feel like he gave me a better understand[ing]." And another: "It was also great to talk to the leaders of these organizations, who demonstrate their passion for the nonprofit efforts."

66 Advocates of community-based learning caution that the value of projects completed by students in many cases may be outweighed by the cost of supervision of the students, and thus, solicitors of community partners must be careful to recognize and acknowledge that the organization is offering a valuable opportunity to the students, rather than vice versa. 
resources than traditional clinical courses, provides an opportunity to utilize transactional skills, and according to the survey of graduates, motivates the students to use the skills developed in the class to work with nonprofit organizations in both volunteer and professional capacities. Further, the educational outcomes are enhanced by inclusion of the experiential component in the class. The students learned more and retained more in their own estimation. Faculty should consider inclusion of similar projects in appropriate courses both to meet the criticisms of current legal education by providing more skills development and to strengthen nonprofit organizations in the community, enhancing social justice. 
Appendix 1 - Survey Administered to Classes from 2005, 2007, and 2008

\begin{tabular}{l} 
Nonprofit Organizations \\
Questionnaire for Law and MBA Graduates who took the \\
Nonprofit Organizations Class \\
\hline \hline Questions \\
* 001: Have you done any nonprofit work since taking the \\
class? \\
Please choose *only one* of the following: \\
$\Gamma$ Yes \\
$\Gamma$ No
\end{tabular}

[Only answer this question if you answered 'Yes' to question '001 ']

* 002: Has your nonprofit work been volunteer, paid or both?

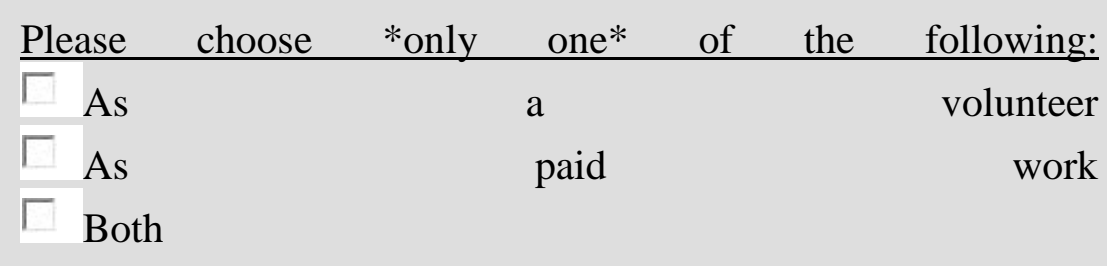

[Only answer this question if you answered 'Yes' to question '001 ']

* 003: Are you currently engaged in either volunteer or paid nonprofit work?

Please choose *only one* of the following: 


\section{ГYes \\ $\Gamma$ No}

[Only answer this question if you answered 'Yes' to question '003 ']

* 004: Is your current nonprofit work volunteer, paid or both?

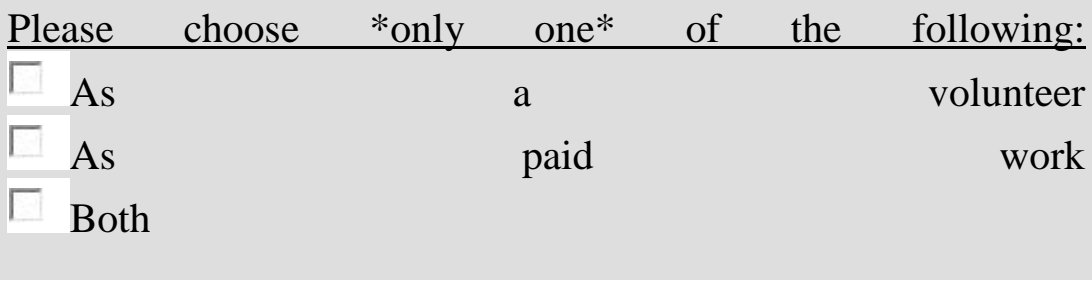

[Only answer this question if you answered 'No' to question '001 ']

* 005: If you have not done any nonprofit work since taking the class, do you expect to do any nonprofit work, paid or unpaid, in the future?

Please choose *only one* of the following:
$\Gamma$ Yes
$\Gamma$ No

* 006: Did the community-based learning component of the class influence your decision to engage or not to engage in nonprofit work?

Please choose *only one* of the following:
$\Gamma$ Yes
$\Gamma$ No


[Only answer this question if you answered 'Yes' to question '006 ']

* 007: Did the community-based learning component make your participation in nonprofit work

Please choose *only one* of the following:

$\Gamma$ More likely
$\ulcorner$ Less likely

* 008: Indicate your agreement or disagreement with the following statements.

Please choose the appropriate response for each item:

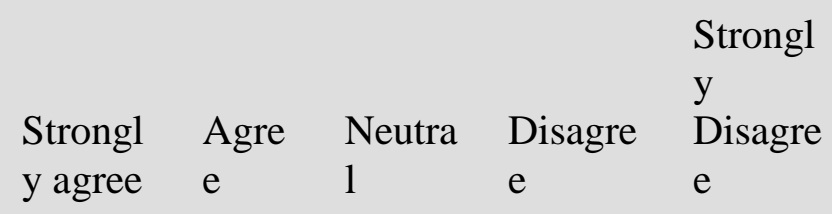

The

community-

based

learning

component

of the course

gave me the

experience, $\Gamma$

skills and

knowledge

to be a more

effective

participant

in nonprofit

work. 


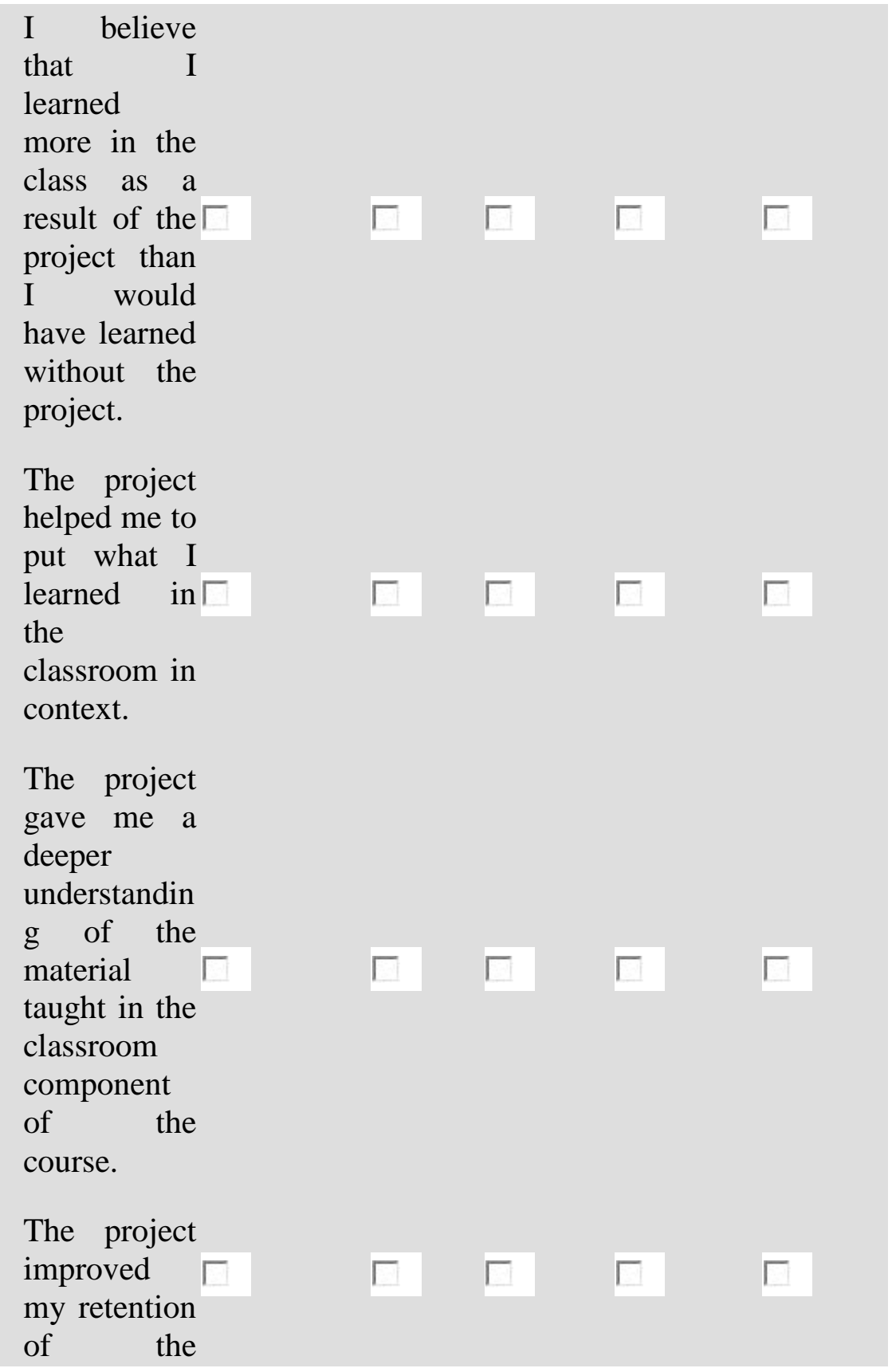




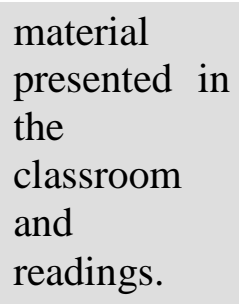

The project provided me with skills and knowledge $\Gamma$ to be a better citizen of the community.

The project increased my passion for law and/or MBA school. 
009: Looking back at the project experience with the benefit of hindsight, what stands out for you from that experience? Is there anything about the project that you would change?
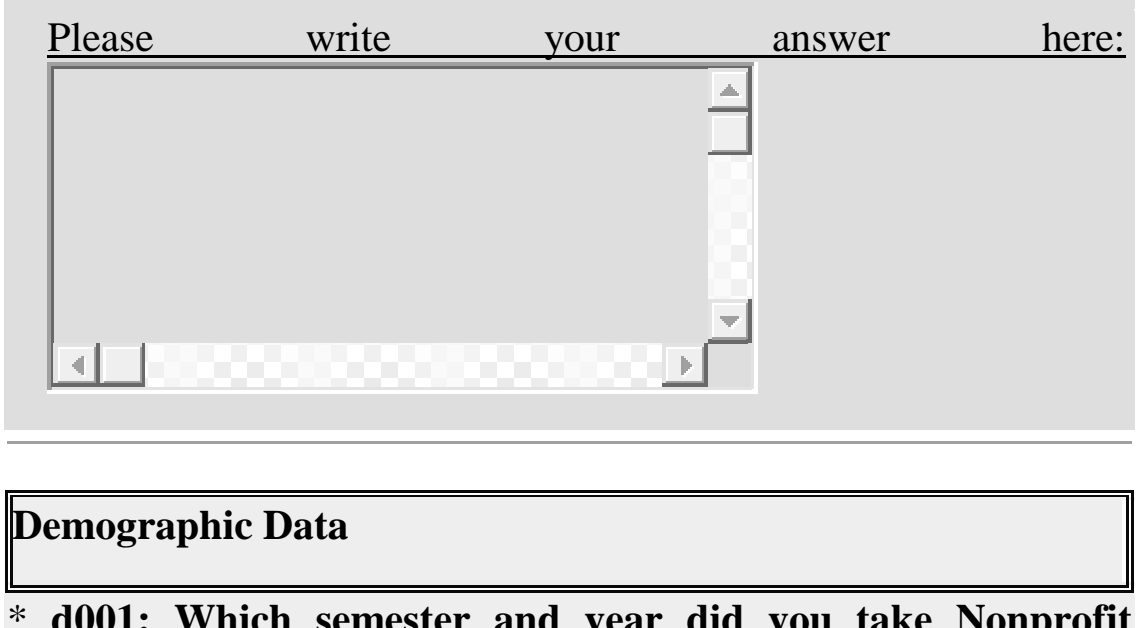

* d001: Which semester and year did you take Nonprofit Organizations?

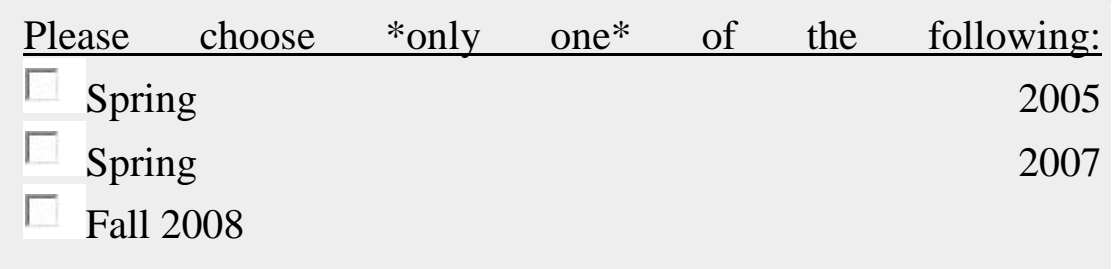

* d002: Which degree did you earn? (Include only the degree(s) toward which you were working when you took the class, not any degrees subsequently earned).

Please choose *all* that apply:
$\Gamma_{\text {Law }}$
$\Gamma_{\text {MBA }}$


$\lceil$ Masters of Accounting

* d003: Did you attend law or MBA school immediately after college?

Please choose *only one* of the following:
$\Gamma$ Yes
$\Gamma$ No

[Only answer this question if you answered 'No' to question 'd003 ']

* d004: If no, were you out of school

\begin{tabular}{|c|c|c|c|c|c|c|}
\hline Please & choose & *only & one* & of & the & following: \\
\hline Г 1-2 & & & & & & years \\
\hline$\Gamma_{3-5}$ & & & & & & years \\
\hline Г 6-10 & & & & & & years \\
\hline$\Gamma$ more & $\tan 10 \mathrm{y}$ & & & & & \\
\hline
\end{tabular}

Submit

Your

Survey.

Thank you for completing this survey.

Appendix 2 - Survey Administered to Spring 2011 Class

\begin{tabular}{|llllll|}
\hline Nonprofit & Organizations & Class & - & Spring & 2011 \\
\hline
\end{tabular}


Questionnaire for Law and Masters of Accounting students who took the Nonprofit Organizations Class in the Spring of 2011

\section{Questions}

* 005: Do you expect to do any nonprofit work, paid or unpaid, in the future?

Please choose *only one* of the following:

$\Gamma$ Yes
$\Gamma$ No

006: Did the community-based learning component of the class influence your decision to engage or not to engage in nonprofit work in the future?

Please choose *only one* of the following:

$\Gamma$ Yes
$\Gamma$ No

[Only answer this question if you answered 'Yes' to question '006 ']

* 007: Did the community-based learning component make your participation in nonprofit work

Please choose *only one* of the following:

$\Gamma$ More likely

$\Gamma$ Less likely

008: Indicate your agreement or disagreement with the following statements. 
$\underline{\text { Please choose the appropriate response for each item: }}$

Strong

Strong

ly

ly

agree

Agr

ee

Neutr

al

Disagr

ee

Disagr

ee

The

communit

y-based

learning

componen

$t$ of the

course

gave me

the

experience $Г$

, skills and

knowledge

to be a

more

effective

participant

in

nonprofit

work.

I believe

that I

learned

more in

the class

as a result

of the

project

than I 
would

have

learned

without

the

project.

The

project

helped me

to put

what IГ

learned in

the

classroom

in context.

The

project

gave me a

deeper

understand

ing of the

material

taught in

the

classroom

componen

$t$ of the

course.

The

project

improved $Г$

my

retention
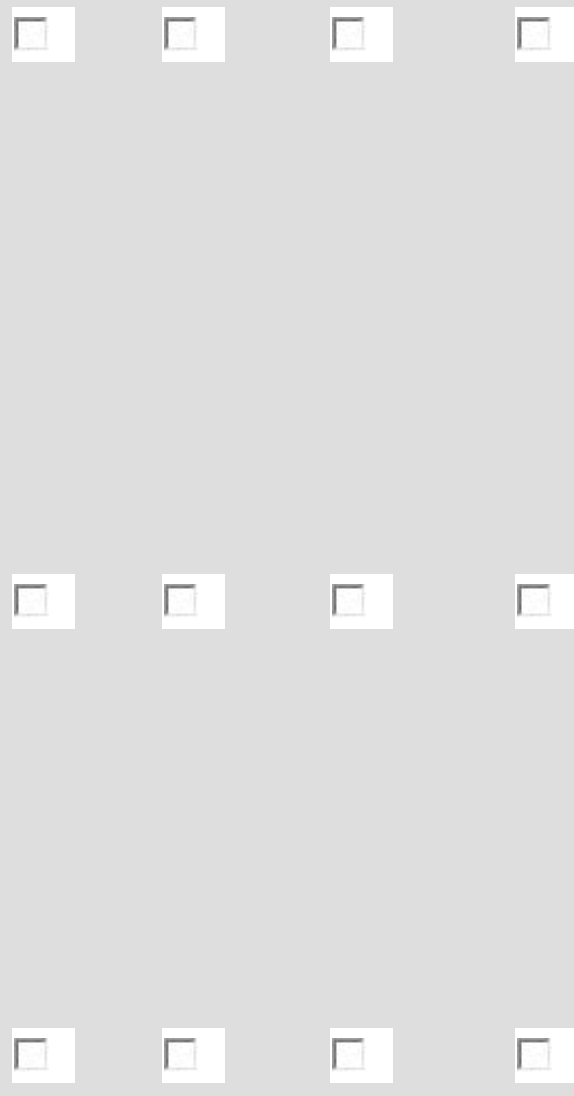


$$
\begin{aligned}
& \text { of the } \\
& \text { material } \\
& \text { presented } \\
& \text { in the } \\
& \text { classroom } \\
& \text { and } \\
& \text { readings. }
\end{aligned}
$$

As a result

of the

communit

y-based

learning

project, I

am better
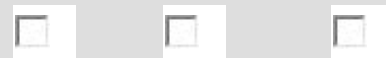

able

to

apply what

I learned

in the

class.

The

project

provided

me with

skills and

knowledge -

to be a
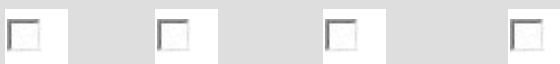

better

citizen of

the

communit

$\mathrm{y}$.

The

project
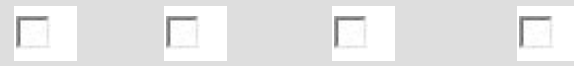
increased

my

passion for

law and/or

the

Accountin

g program.

009: Looking back at the project experience, what stands out for you from that experience? Is there anything about the project that you would change?
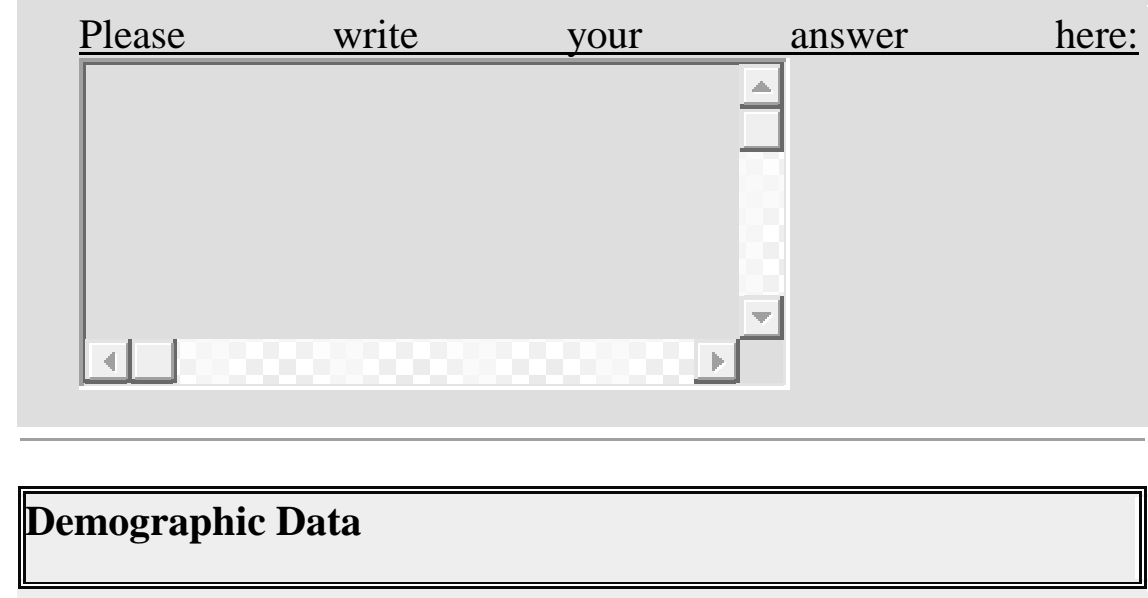

* d002: Which degree did are you seeking?

Please choose *all* that apply:

$\Gamma$ Law

$\Gamma \mathrm{MBA}$

$\lceil$ Masters of Accounting

* d003: Did you attend law school or the Masters of 
Accounting program immediately after college?

Please choose *only one* of the following:

$\Gamma_{\text {Yes }}$
$\ulcorner$ No

[Only answer this question if you answered 'No' to question 'd003 ']

* d004: If no, were you out of school

Please choose *only one* of the following:

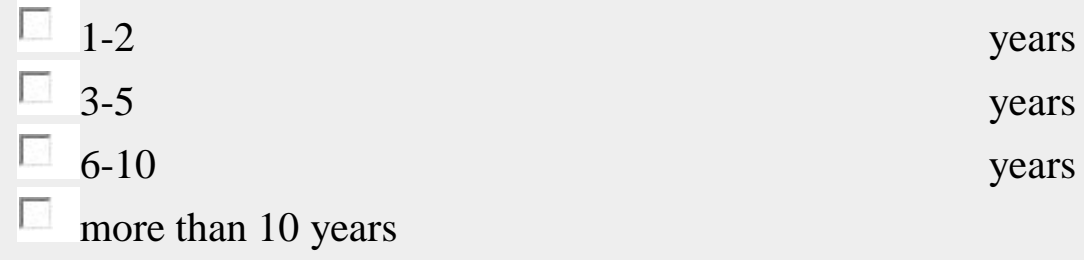

\begin{tabular}{lll}
\hline Submit & Your & Survey.
\end{tabular}

Thank you for completing this survey. 